\title{
Wrch-1, a novel member of the Rho gene family that is regulated by Wnt-1
}

\author{
Weikang Tao, ${ }^{1}$ Diane Pennica, ${ }^{2}$ Lifeng Xu ${ }^{1}{ }^{1}$ Robert F. Kalejta, ${ }^{1}$ and Arnold J. Levine ${ }^{3,4}$ \\ ${ }^{1}$ Department of Molecular Biology, Princeton University, Princeton, New Jersey 08544, USA; ${ }^{2}$ Department of Molecular \\ Oncology, Genentech, Inc., South San Francisco, California 94080, USA; ${ }^{3}$ The Rockefeller University, New York, \\ New York 10021-6399, USA
}

\begin{abstract}
We report the isolation and cloning of the Wrch-1 (Wnt-1 responsive Cdc42 homolog) cDNA. Wrch-1 is a novel gene whose mRNA level increases in response to Wnt-1 signaling in Wnt-1 transformed cells, Wnt-1 transgene induced mouse mammary tumors, and Wnt-1 retrovirus infected cells. Wrch-1 encodes a homolog of the Rho family of GTPases. It shares $57 \%$ amino acid sequence identity with Cdc42, but possesses a unique N-terminal domain that contains several putative PXXP SH3-binding motifs. Like Cdc42, Wrch-1 can activate PAK-1 and JNK-1, and induce filopodium formation and stress fiber dissolution. Active Wrch-1 stimulates quiescent cells to reenter the cell cycle. Moreover, overexpression of Wrch-1 phenocopies Wnt-1 in morphological transformation of mouse mammary epithelial cells. Taken together, Wrch-1 could mediate the effects of Wnt-1 signaling in the regulation of cell morphology, cytoskeletal organization, and cell proliferation.
\end{abstract}

[Key Words: Wrch-1; Wnt-1; $\beta$-catenin; Cdc42; Rho; GTPase]

Received March 9, 2001; revised version accepted May 22, 2001.

The Wnt/Wingless signaling pathway is fundamentally important for the development of organisms ranging from nematodes to mammals, where it functions to regulate cell morphology and polarity, modulate cellcell adhesion and cell motility, specify cell fate, and control cell proliferation (Cadigan and Nusse 1997). Genetic studies in Drosophila in combination with biochemical experiments in Xenopus and mammalian cells have established a molecular framework for this pathway, which involves interactions between extracellular molecules and membrane receptors, an intracellular signal transduction, and the regulation of gene expression (Dale 1998; Dierick and Bejsovec 1999). In mammals, the Wnt family proteins initiate signaling by binding to their cognate receptors, Frizzled (Fz), on the plasma membrane. The agonist-bound $\mathrm{Fz}$ can activate a cytoplasmic protein, disheveled (Dsh), which in turn inhibits the kinase activity of glycogen synthase kinase- $3 \beta$ (GSK-3 $\beta$ ). In the absence of Wnt signaling, GSK-3 $\beta$ constitutively phosphorylates the oncoprotein $\beta$-catenin (Polakis 1999), which induces a ubiquitin-dependent degradation of $\beta$-catenin mediated by a complex of proteins consisting of the tumor suppressor protein, adenomatous polyposis coli (APC), axin (Zeng et al. 1997), and a member of the SCF ubiquitin ligase complex, $\beta$-TrCP (Latres et al. 1999). Thus, Wnt signaling results in the stabilization and accumulation of $\beta$-catenin in the cytoplasm. The

\footnotetext{
${ }^{4}$ Corresponding author.

E-MAIL alevine@rockvax.rockefeller.edu; FAX (212) 327-8900.

Article and publication are at http://www.genesdev.org/cgi/doi/10.1101/ gad.894301.
}

elevated levels of $\beta$-catenin promote its oligomerization with a member of the TCF/LEF transcription factor family. The complex of $\beta$-catenin and TCF/LEF translocates into the nucleus, where it serves as a functional transcription factor to activate the transcription of downstream genes. In addition to this canonical model of Wnt signaling, a new view has recently emerged, in which a Wnt signal can induce gene expression in a $\beta$-catenin independent and protein kinase $\mathrm{C}(\mathrm{PKC})$ sensitive manner (Miller et al. 1999; Kuhl et al. 2000; Ziemer et al. 2001). Conceivably, Wnt signaling could also modulate gene expression indirectly by controlling the expression of other transcription factors.

The Wnt signaling pathway is not only developmentally important but also implicated in tumorigenesis (Peifer and Polakis 2000; Polakis 2000). Wnt-1 was originally identified as an oncogene, whose activation upon the insertion of mouse mammary tumor virus (MMTV) proviral DNA resulted in the formation of mouse mammary adenocarcinoma (Nusse et al. 1984). MMTVWnt-1 transgenic mice develop tumors in both mammary and salivary glands (Tsukamoto 1988). Overexpression of some Wnt-1-related proteins, such as Wnt-2 and Wnt-5A, has been observed in human colon and breast cancers (Lejeune et al. 1995; Vider et al. 1996). In addition, mutations in the APC gene that eliminate its ability to promote $\beta$-catenin degradation occur in up to $80 \%$ of human colon carcinomas (Polakis 1999). Mutations of $\beta$-catenin that lead to the stabilization of this oncoprotein are detected in colon cancers, melanomas, hepatocellular carcinomas, and pilomatricomas (Morin 
et al. 1997; Rubinfeld et al. 1997; de La Coste et al. 1998; Chan et al. 1999).

The biological effects of Wnt signaling in both development and tumorigenesis are largely mediated by its direct or indirect transcriptional target genes. Recently, an array of genes have been identified as Wnt-1 inducible genes, which include cyclin D1 (Tetsu and McCormick 1999), c-myc (He et al. 1998a), Wnt-1 Induced Secreted Protein 1 (WISP-1) (Pennica et al. 1998), and c-Jun (Mann et al. 1999). However, even those newly described genes cannot account for the diverse functions of Wnt signaling. For instance, the molecular mechanisms of Wnt signaling in the regulation of cell morphology, cell-cell adhesion, cell-extracellular matrix interactions, cell migration, and cell proliferation remain elusive.

The Rho family GTPases, including Rho, Rac, and Cdc42, are key regulators of the actin cytoskeleton and play a central role in a wide range of physiological processes, which include cell morphology, cell adhesion, cytokinesis, cell motility, and cell growth (Van Aelst and D'Souza-Schorey 1997; Hall 1998). Overexpression or aberrant activation of these proteins is involved in malignant transformation, tumor formation, and metastasis (Michiels et al. 1995; Qiu et al. 1995; Keely et al. 1997; Clark et al. 2000). While genetic studies in Drosophila suggest that RhoA could act downstream of Fz and Dsh to mediate the effect of Wnt signaling in correct establishment of planar polarity in epidermis (Strutt et al. 1997), a biological link of the Wnt pathway and the Rho family proteins in vertebrates has not been observed.

In an attempt to identify additional genes that are directly or indirectly regulated by Wnt- 1 signaling and that are relevant to transformation and tumor formation, a cDNA subtraction analysis was carried out between a Wnt-1 expressing mouse mammary epithelial cell line (C57MG/Wnt-1) and the parental cell line (C57MG). From this analysis, we identified a novel gene, Wrch-1 (Wnt-1 responsive Cdc42 homolog), that is differentially expressed in Wnt-1 expressing cells and MMTV-Wnt-1 transgenic mouse mammary tumors, and that is rapidly induced by Wnt-1 signaling. Interestingly, Wrch-1 encodes a structural and functional homolog of the Rho family of GTPases. While most members of the Rho family are constitutively expressed (Ridley 1999), the expression of Wrch-1 is rapidly induced upon the activation of the Wnt-1 pathway. In addition, an SH3 binding domain at the amino-terminus of Wrch-1 suggests that this protein may be regulated through protein-protein interactions. A number of biological activities of Wrch-1 are demonstrated in this report. Based on these results, Wrch-1 has the potential to mediate the effect of Wnt-1 on cell morphology and to contribute to the ability of Wnt-1 to transform cells and induce tumor formation.

\section{Results}

Isolation of Wrch-1 as a putative downstream target gene of Wnt-1

To identify putative downstream target genes of Wnt-1 signaling, a PCR-select cDNA subtraction analysis was carried out between parental C57MG cells, the mouse mammary epithelial cells that do not express Wnt-1, and C57MG/Wnt-1 cells that stably express Wnt-1 (Pennica et al. 1998). C57MG cells were chosen for this experiment because aberrant activation of Wnt-1 expression in this type of cell in the mouse mammary gland results in hyperplasia, and Wnt-1 can morphologically transform these cells in vitro (Nusse et al. 1984; Jue et al. 1992; Mason et al. 1992). Therefore, C57MG cells provide an in vitro model system for studying Wnt-1 signaling and for identifying genes that are downstream of Wnt-1 and that may be involved in Wnt-1-induced cell transformation. C57MG/Wnt-1 cells were generated by infecting C57MG cells with a Wnt-1-expressing retrovirus (Pennica et al. 1998). Cells that stably express Wnt-1 for three weeks after infection were used in the cDNA subtraction analysis, as it could then allow for the identification of both direct and indirect target genes of Wnt-1 signaling. From this analysis, the Wrch-1 gene was isolated as one of the genes that was differentially expressed in C57MG/ Wnt-1 cells versus the parental C57MG cells (Pennica et al. 1998; Ziemer et al. 2001).

To confirm that Wrch-1 is regulated by Wnt-1 signaling, C57MG cells were infected with either an empty retroviral vector or a Wnt-1-expressing retrovirus. Six days after infection, RNA was isolated and the expression of Wrch-1 was determined by Northern blot analysis. As shown in Figure 1A, Wrch-1 mRNA is up-regulated more than fourfold in C57MG/Wnt-1 cells versus C57MG/vector cells.

Since $\beta$-catenin is downstream of Wnt- 1 in the Wnt signaling pathway and can mediate transcriptional activation of Wnt-1 induced genes (Polakis 1999), the effect of $\beta$-catenin on Wrch-1 expression was assessed. C57MG cell lines overexpressing two stabilized mutants of $\beta$-catenin, 4145 and $4145 \mathrm{TV}$, were generated by transfection (Xu et al. 2000). The mutant 4145 has both Thr 41 and Ser 45 at the N-terminal GSK-3 $\beta$ phosphorylation sites changed to alanines. The other mutant, 4145TV, has the above mutations as well as mutations that change Thr 120 and Val 122 to alanines in the $\alpha$-catenin binding region, which abrogates its ability to bind $\alpha$-catenin. Northern blot analysis showed that the Wrch-1 transcript was not increased in C57MG cells that overexpressed 4145 or 4145 TV (Fig. 1A). However, both 4145 and 4145TV dramatically induced the expression of WISP1, another Wnt-1 responsive gene, in a similar experiment (Xu et al. 2000). These results suggest that Wnt-1 may up-regulate Wrch-1 expression in a $\beta$-catenin independent manner.

To determine the temporal regulation of Wrch-1 by Wnt-1 signaling, C57MG cells were cocultured with either parental QT6 cells (quail fibrosarcoma cells) that do not express Wnt-1, or QT6 cells that stably express Wnt-1 (QT6/Wnt-1) (Parkin et al. 1993), for various times. Wrch-1 mRNA levels were then determined by a Northern blot. This coculture experiment establishes a paracrine signaling system within the tissue culture plate, in which the Wnt-1 molecules produced and secreted by QT6/Wnt-1 cells elicit a response and induce 

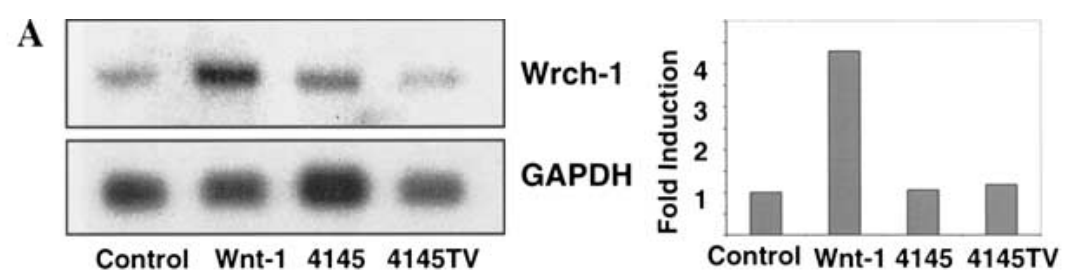

B
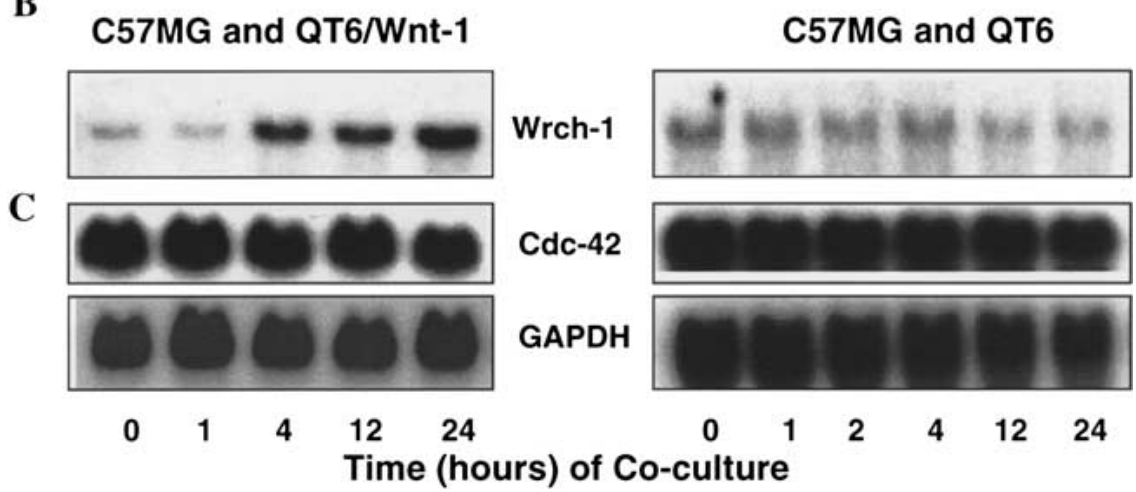

Figure 1. Wnt-1 signaling induces Wrch-1, but not Cdc-42. (A) Northern blot analysis of Wrch-1 expression in cells expressing Wnt-1, 4145 , or 4145 TV was performed using a 393 bp mouse Wrch-1-specific probe (containing codons for amino acids 81-211). Blots were rehybridized with a mouse GAPDH probe for loading control. Fold induction of Wrch-1 over the vector control was represented after normalizing to GAPDH levels. (B) C57MG cells were cocultured with either the parental QT6 cells or the QT6/Wnt-1 cells. Total RNA was extracted from the coculture at indicated time points, and Northern blotting was performed using the mouse Wrch-1 probe described above. Levels of GAPDH as a loading control are shown in $C .(C)$ Cdc42 mRNA levels in the coculture were determined by reprobing the blots described in $B$ with a Cdc42 cDNA probe (containing codons for amino acids 1-103).

gene expression in mouse C57MG cells (Parkin et al. 1993; Ziemer et al. 2001). When C57MG cells were cocultured with QT6/Wnt-1 cells, the transcripts of Wrch-1 were induced $\sim$ sixfold after $4 \mathrm{~h}$ of coculture, and sustained at high levels throughout a 24-h coculture experiment (Fig. 1B). However, no induction of Wrch-1 expression was detected when C57MG cells were cocultured with parental QT6 cells (Fig. 1B). These data show that Wnt-1 can induce Wrch-1 mRNA levels in cell coculture. RNA isolated from cocultures contains RNA from C57MG cells as well as RNA from QT6 or QT6/ Wnt-1 cells. The mouse Wrch-1 cDNA probe used in these experiments does not cross hybridize with the quail Wrch-1 mRNA (data not shown).

In order to determine the biological relevance of Wrch-1 as a downstream target gene of Wnt-1 signaling, the Wrch-1 transcript levels were determined in MMTVWnt-1 transgenic mouse mammary tumors (Tsukamoto 1988) as well as in normal, wild-type mouse mammary glands by Northern blot analysis. Although there was a difference in the amount of sample loaded between normal mouse mammary glands and mouse mammary tumors, Wnt-1 or Wrch-1 transcripts were not detectable in normal mouse mammary glands (Fig. 2). However, both Wnt-1 and Wrch-1 mRNAs were highly expressed in two independent Wnt-1 transgenic mouse mammary tumors. These results establish a strong correlation between overexpression of Wnt-1 and elevated levels of the Wrch-1 message in vivo.

\section{Identification of Wrch-1 as a homolog of the Rho} family of GTPases

Based on the partial sequence of mouse Wrch-1 cDNA isolated from PCR-select cDNA subtraction, the fulllength mouse and human Wrch-1 cDNAs were cloned. The cDNAs of human and mouse Wrch-1 encode proteins of 258 and 261 amino acid residues, respectively,

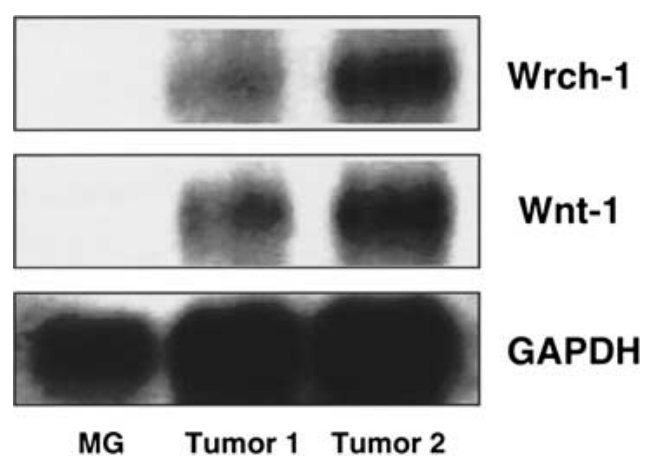

Figure 2. Expression of Wrch-1 and Wnt-1 in Wnt-1 transgenic mouse mammary tumors, but not in normal, wild-type mouse mammary glands. Total RNA was extracted from wild-type mouse mammary glands (MG) and two independent MMTVWnt-1 transgenic mouse mammary tumors. Levels of the Wrch-1 transcript were assessed by Northern blot analysis. The blots were reprobed with the full-length mouse Wnt-1 cDNA $(2.2 \mathrm{~kb})$ to determine levels of the Wnt-1 mRNA. 
which are $92 \%$ identical (Fig. 3). Analysis of the deduced amino acid sequence of Wrch-1 identifies it as a homolog of the Rho family of GTPases. The human Wrch-1 protein shares $57 \%$ identity and $70 \%$ similarity with Cdc 42 , and $30 \%-55 \%$ similarity with other members of the Rho family. Both human and mouse Wrch-1 contain GTP and GDP binding domains, the effector domain, and a CAAX lipid modification signal at their $\mathrm{C}$ termini, all of which are conserved among most members of the Rho family (Fig. 3) (Ridley 1999). In addition, both human and mouse
Wrch-1 possess a unique N-terminal domain that contains several putative PXXP SH3-binding motifs (Fig. 3).

Since Wrch-1 is highly homologous to Cdc42, we determined whether the expression of Cdc42 was also regulated by Wnt-1 signaling. The blots used for assessing the effect of Wnt-1 on Wrch-1 expression were reprobed with a Cdc42 cDNA probe. As shown in Figure 1C, levels of the Cdc42 transcript were constitutively high and were not regulated by Wnt-1 signaling in either the coculture experiment (Fig. 1C) or the retroviral infection (data not

\section{N-terminal domain}

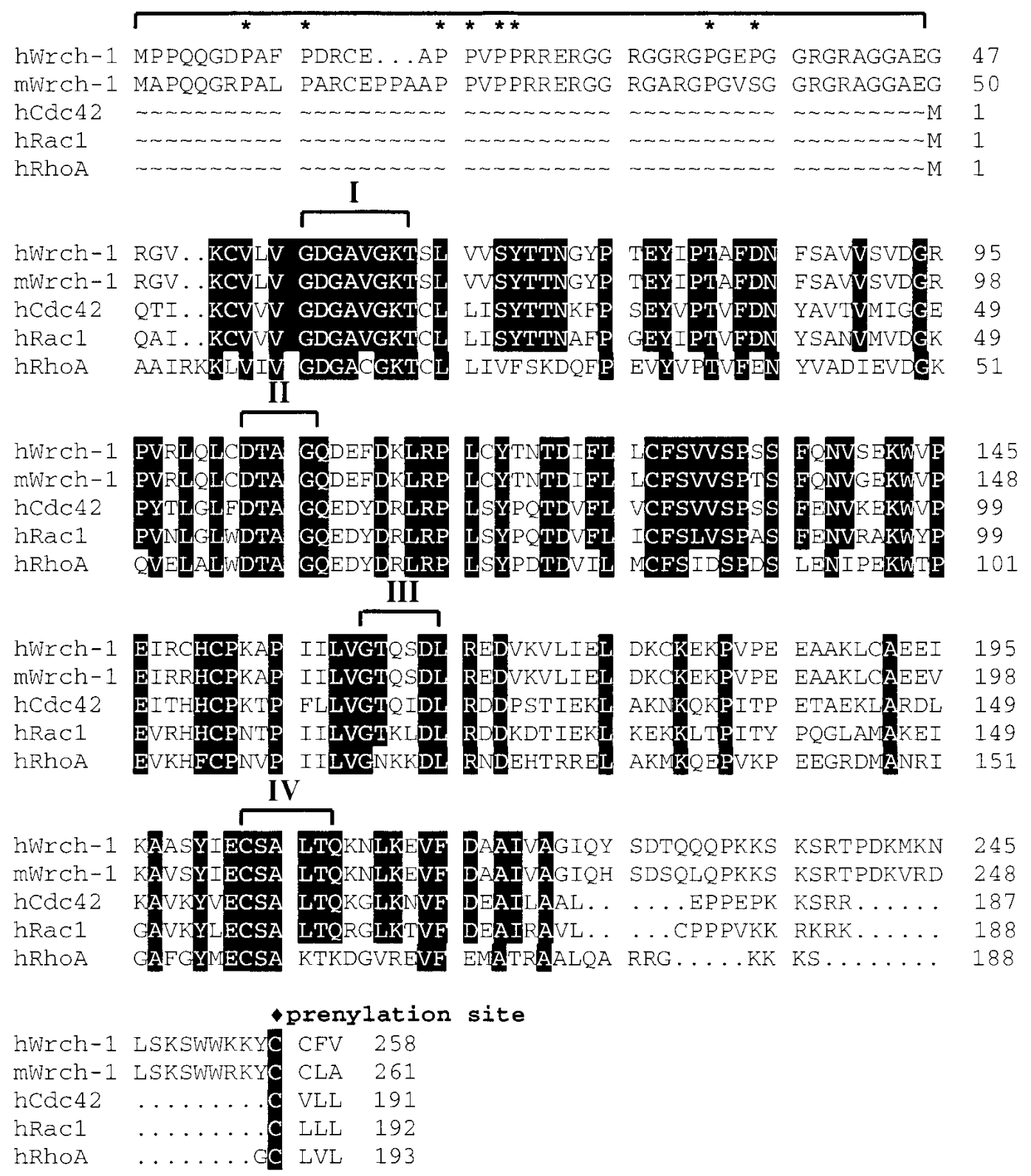

Figure 3. Amino acid sequences and domain structure of human and mouse Wrch-1. The deduced amino acid sequences of human and mouse Wrch-1 (hWrch-1 and mWrch-1) were aligned with those of human Cdc42, Rac-1, and RhoA. Identity across these proteins is denoted by black boxes. Nucleotide binding domains I-IV are indicated above the sequences. The proline residues in the unique $\mathrm{N}$-terminal domain of Wrch-1, that are predicted to form PXXP SH3 binding motifs, are indicated by asterisks. The conserved cysteine residues at the $\mathrm{C}$-termini of these proteins that serve as the prenylation site are indicated. 
Tao et al.

shown). These results are consistent with the previous reports that most members of the Rho family, including Cdc42, are constitutively and widely expressed in many tissues (Ridley 1999). Thus, Wrch-1 is not only structurally unique, but is also regulated by Wnt-1 signaling.

Expression of Wrch-1 in adult human tissues and mouse embryos

Tissue-specific expression of Wrch-1 in adult human tissues was determined by Northern blot analysis. A hu- man Wrch-1-specific probe hybridized to a $4.4 \mathrm{~kb}$ mRNA species in several human tissues (Fig. 4A). The highest Wrch-1 expression was detected in the brain, skeletal muscle, and placenta. Moderate expression was seen in the liver, lung, and heart. Low levels of expression were observed in the colon, spleen, kidney, and small intestine. Little or no expression was detected in the thymus and peripheral blood leukocytes (PBL). Since Wnt-1 is predominantly expressed in the testis of adult mice (Shackleford and Varmus 1987), it is possible that other Wnt-1-related proteins or other signaling molecules could induce the expression of Wrch-1 in other tissues.

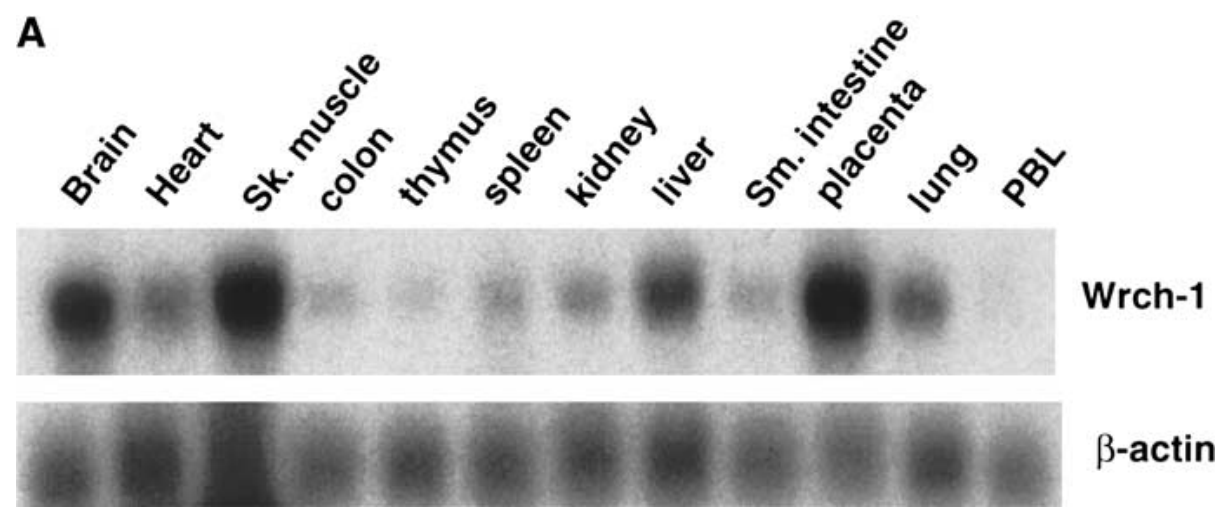

B

Antisense

E12 mouse spinal cord
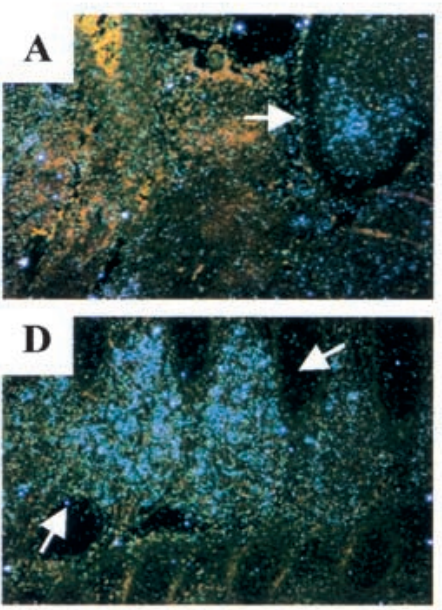

E15 mouse dorsal root ganglion of spinal cord

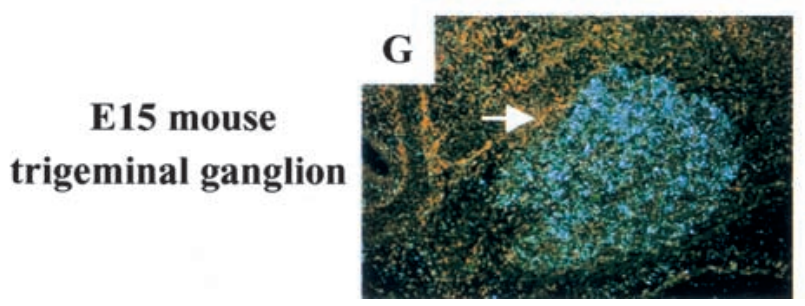

Sense
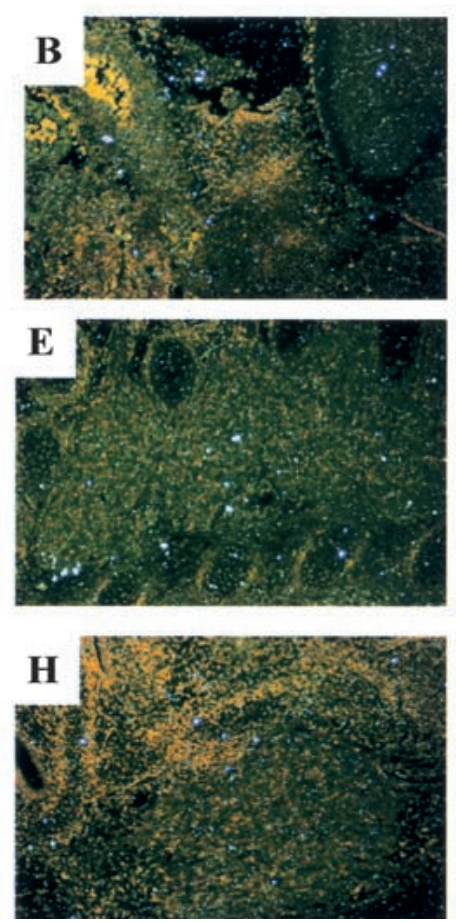

H\&E
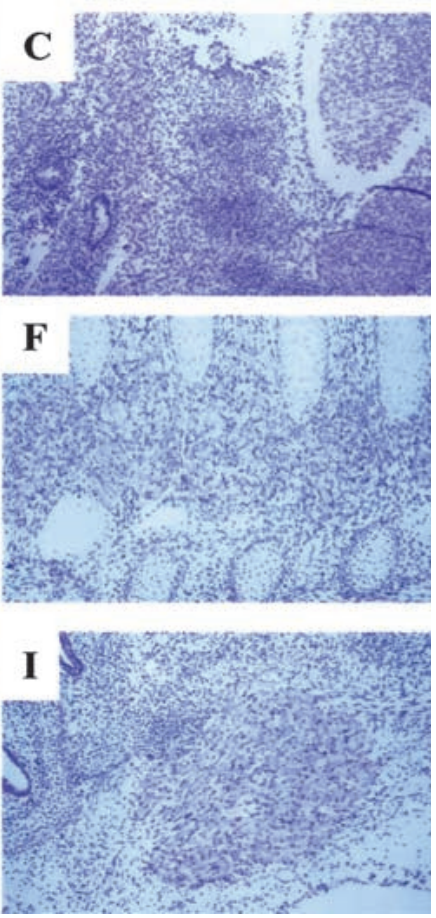

Figure 4. Expression of the Wrch- 1 mRNA in adult human tissues and mouse embryos. $(A) \operatorname{Poly}(\mathrm{A})^{+}$RNA blots containing $2 \mu \mathrm{g}$ of poly $(\mathrm{A})^{+}$RNA per lane from multiple human tissues were hybridized with a human Wrch-1 cDNA probe (containing codons for amino acids 81-207). The same filter was reprobed with human $\beta$-actin as a loading control. (B) Expression of the Wrch-1 mRNA in mouse embryos. In situ hybridization was performed on serial sections from various developmental stages using either a mouse Wrch-1 antisense or sense probe. Sections were also stained with hematoxylin/eosin (H\&E) to visualize the tissue. Representative images are shown. Panels $A, D$, and $G$ show Wrch-1 expression in E12 spinal cord, E15 dorsal root ganglion of the spinal cord, and E15 trigeminal ganglion, respectively. Sites of Wrch-1 expression are indicated by arrows. 
Wrch-1 expression in the mouse embryo was assessed by in situ hybridization (Fig. 4B). Strong expression was observed in the nervous system, including the spinal cord and the trigeminal ganglion in the brain, as well as the uterine myometrium (data not shown). Since Wnt-1 signaling is of vital importance during embryonic development of the central nervous system in mice (Shackleford and Varmus 1987; McMahon and Bradley 1990), Wrch-1 could play a role in this process.

\section{Characterization of the biochemical and biological activities of Wrch-1}

The high homology between Wrch-1 and the Rho family proteins suggests that Wrch-1 may have similar biological activities. The Rho family proteins include three subfamilies: Rho, Rac, and Cdc42 (Vojtek and Cooper 1995; Van Aelst and D'Souza-Schorey 1997). These small GTPases are involved in many important physiological processes. For instance, Cdc42 and Rac can activate PAK (p21-activated protein kinase) (Manser et al. 1994) and JNK (Jun N-terminal kinase) (Coso et al. 1995; Minden et al. 1995). Cdc42, Rac, and Rho can regulate the actin cytoskeletal organization and stimulate cell cycle progression (Van Aelst and D'Souza-Schorey 1997; Hall 1998). Therefore, we sought to determine whether Wrch-1 can (1) activate PAK-1 and JNK-1; (2) regulate the actin cytoskeletal structure; and (3) stimulate cell cycle progression.

To this end, we made a putative constitutively active mutant of Wrch-1, Wrch-1Q107L, and a putative dominant negative mutant, Wrch-1T63N, by analogy with similar mutants of Cdc42 and Rac (Ridley 1999). The mutant Q107L was predicted to be defective in hydrolysis of GTP and thus it would be locked in the GTP bound form. In contrast, the mutant $\mathrm{T} 63 \mathrm{~N}$ was presumably unable to bind to nucleotides and it would therefore be locked in the inactive conformation. Moreover, this mutant could function in a dominant negative way by competing for the Wrch-1 nucleotide exchange factor(s).

To determine whether Wrch-1 is able to activate PAK1, a hemagglutinin (HA) tagged PAK-1 plasmid was cotransfected into COS-7 cells with either an empty vector, or one or more of the constructs encoding wild-type Wrch-1, Q107L, or T63N. Thirty-six hours after transfection, the cells were harvested and the HA-PAK-1 was immunoprecipitated using an anti-HA antibody. Subsequently, an in vitro protein kinase assay was performed. Because PAK-1 can undergo autophosphorylation after its activation (Martin et al. 1995), in this assay PAK-1 was used as both a kinase and a substrate. Figure 5A shows that coexpression of wild-type Wrch-1 stimulated the activation of PAK-1. As predicted, the constitutively active mutant, Q107L, had an augmented activity in the activation of PAK-1, while the dominant negative mutant, T63N, failed to activate PAK-1. Furthermore, coexpression of T63N with wild-type Wrch-1 inhibited Wrch1-triggered activation of PAK-1 (Fig. 5A). Using a similar assay, the constitutively active mutant Q107L activated JNK-1 (Fig. 5B). However, activation of JNK-1 by wild-

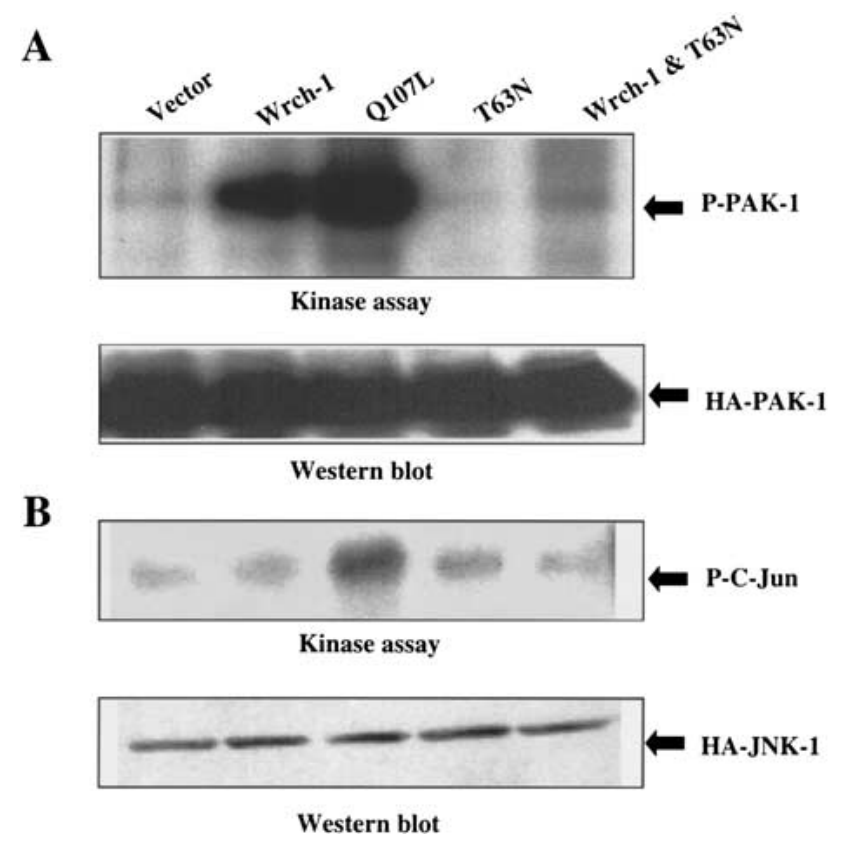

Figure 5. Wrch-1 activates PAK-1 and JNK-1. (A) COS-7 cells were cotransfected with the HA-PAK-1 plasmid $(3 \mu \mathrm{g})$ and either the empty vector or one of the plasmids $(3 \mu \mathrm{g})$ encoding Wrch-1, $\mathrm{Q} 107 \mathrm{~L}$, and $\mathrm{T} 63 \mathrm{~N}$, or a combination of plasmids encoding Wrch-1 and T63N (1.5 $\mu \mathrm{g}$ each). $36 \mathrm{~h}$ after transfection, HAPAK1 was immunoprecipitated, and the kinase activity of PAK-1 was determined by assessing autophosphorylation of PAK-1 using the immunocomplex kinase assay. Radiolabeled products of the assay were separated by SDS-PAGE and visualized by autoradiography (upper panel). Phosphorylated PAK-1 (P-PAK-1) is indicated. Levels of PAK-1 in each sample were determined by Western blotting and shown to be similar (lower panel). (B) COS-7 cells were cotransfected with a HA-JNK-1 plasmid and the plasmid(s) as described above. $24 \mathrm{~h}$ later, cells were serum-starved for $16 \mathrm{~h}$, and then HA-JNK-1 was immunoprecipitated. The activity of JNK-1 was determined by the immunocomplex kinase assay using GST-C-Jun as a substrate. Products of the kinase assay were separated by SDS-PAGE and revealed by autoradiography (upper panel). Phosphorylated CJun is indicated (P-C-Jun). Levels of HA-JNK-1 were assessed by Western blot analysis and shown to be similar (lower panel).

type Wrch-1 was only poorly or not observed at all. This lack of activation by wild-type Wrch-1 may result from a modification of the experimental procedures in assessing JNK-1 activation versus those in assessing PAK-1 activation. To reduce the nonspecific JNK-1 kinase activity in COS-7 cells, the cells must be serum-starved for $16 \mathrm{~h}$ before they are assayed, whereas there is no need to serum-starve these cells to test PAK-1 activation. Serum may elicit the activation of ectopically expressed Wrch1. In addition, the binding of Wrch-1 to PAK-1 was determined in the coimmunoprecipitation assay. Only the constitutively active mutant of Wrch-1, Q107L, but not the dominant negative mutant, T63N, binds to PAK-1 (data not shown). Taken together, these data indicate that like Cdc42 and Rac, Wrch-1 can activate PAK-1 and JNK-1 at least with a constitutively active Wrch-1 mutant. Moreover, these results confirmed the biological 
activities of Q107L as a constitutively active mutant and T63N as a dominant negative mutant of Wrch-1.

Next, the effect of Wrch-1 on the actin cytoskeletal structure was determined. For this purpose, Wrch-1 recombinant adenoviruses were made that constitutively expressed the Wrch-1 mutants, Q107L, and T63N, or $\beta$-galactosidase (as a control). All of these viruses also expressed green fluorescent protein (GFP), allowing the use of GFP as a marker to identify the infected cells. These viruses were employed to infect Swiss 3T3 cells. Twelve hours after infection, the cells were serumstarved for $24 \mathrm{~h}$, and then fixed and stained for F-actin. The structure of the actin cytoskeleton was analyzed by confocal immunofluorescent microscopy. In cells expressing the constitutively active mutant of Wrch-1, Q107L, there was a dissolution of stress fibers (Fig. 6). In addition, similar to Cdc42-induced filopodia (Kozma et al. 1995; Nobes and Hall 1995), these cells formed the finger-like protrusions that were composed of F-actin. Neither the dominant negative mutant of Wrch-1, T63N, nor $\beta$-galactosidase exhibited this phenotype. These data indicate that like Cdc42, Wrch-1 can modulate actin cytoskeletal organization by inducing the formation of filopodia and the dissolution of stress fibers.

The effect of Wrch-1 on cell cycle progression was also determined. Adenoviruses that expressed $\beta$-galactosidase, E2F-1, Wrch-1Q107L, and T63N were used to infect quiescent Swiss 3T3 cells that had been serumstarved for $48 \mathrm{~h}$. After infection, cells were cultured un- der serum-starved conditions for $48 \mathrm{~h}$ before they were collected. Their distribution in the cell cycle was determined by measuring the DNA content of cells using FACS analysis. As shown in Figure 7, cells infected with the adenoviruses expressing $\beta$-galactosidase show only a slight increase in the fraction at the S-phase, as compared to the profile of noninfected cells. This may be a result of the virus infection. Consistent with previous observations, overexpression of E2F-1 stimulated cell cycle progression through the $G_{1}$ phase and DNA synthesis, and at the same time induced apoptosis (note the increase in the fraction of cells containing subdiploid DNA) (Shan and Lee 1994). Similarly, overexpression of the active form of Wrch-1, Q107L, promoted cell cycle progression through the $\mathrm{G}_{1}$-phase and increased the number of cells undergoing apoptosis. However, T63N, the dominant negative mutant, had no effect on stimulating cell cycle progression, but its overexpression did increase cell death at a small amount. These results suggest that Wrch-1 can stimulate cell cycle progression through the $\mathrm{G}_{1}$-phase and DNA synthesis.

\section{Expression of Wrch-1 mimics the effect of Wnt-1 in C57MG cells}

As mentioned before, overexpression of Wnt-1 in mouse mammary epithelial cells (C57MG) by retroviral infection morphologically transforms these cells, which manifests as an increased refractility, elongated mor-
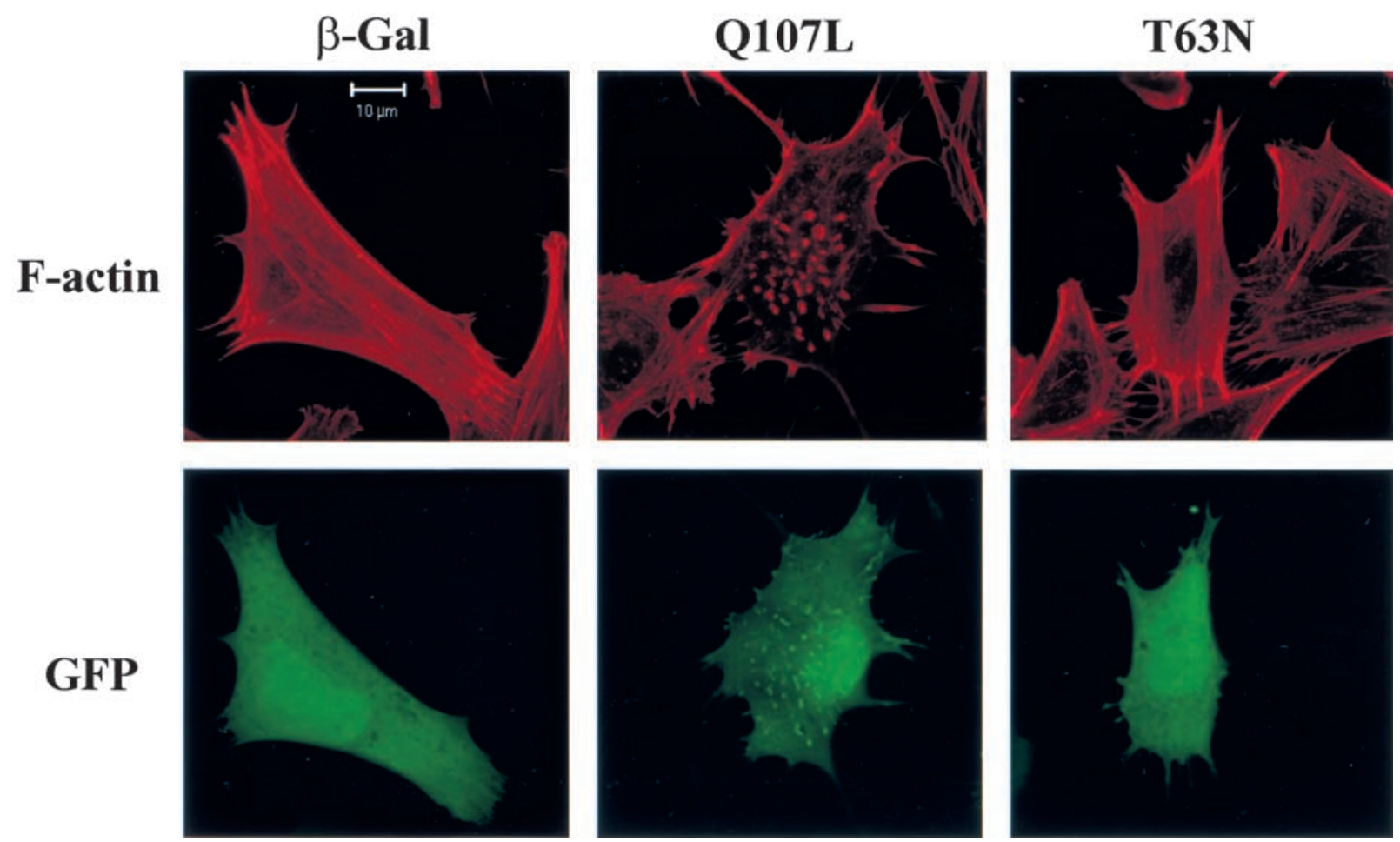

Figure 6. Wrch-1 induces filopodium formation and stress fiber dissolution in Swiss 3T3 cells. Swiss 3 T3 cells were infected with the recombinant adenoviruses expressing $\beta$-galactosidase ( $\beta$-gal), Q107L, or T63N. All of these viruses express GFP. Twelve hours after infection, cells were serum-starved for $24 \mathrm{~h}$, and then fixed and stained for F-actin. The structure of F-actin and expression of GFP were detected by confocal immunofluorescent microscopy. A scale bar is shown in the image. 


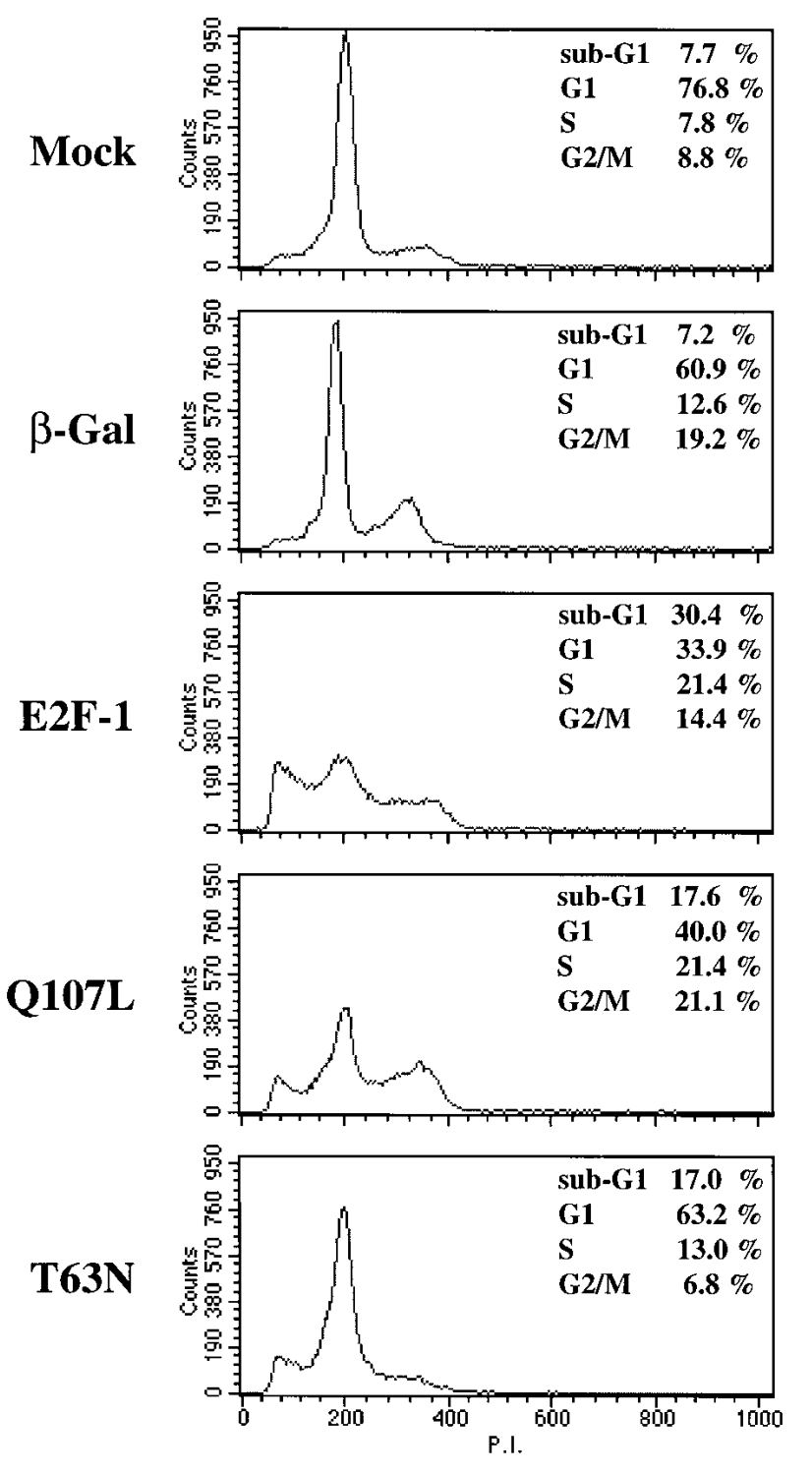

Figure 7. Wrch-1 stimulates quiescent Swiss $3 \mathrm{~T} 3$ cells to reenter the cell cycle. Swiss 3T3 cells were rendered quiescent by culturing in the absence of serum for $48 \mathrm{~h}$. They were then infected with recombinant adenoviruses expressing $\beta$-galactosidase, E2F-1, Q107L, or T63N. Mock-infected cells were included as a control. After culturing without serum for $48 \mathrm{~h}$, cells were fixed, stained with P.I., and analyzed by flow cytometry. The histogram plots of cell number versus DNA content are presented. The percentages of cells in different phases of cell cycle based on their DNA contents are indicated.

phology, higher saturation density, and a conversion from a monolayer to a multilayered growth (Mason et al. 1992). All of these phenotypes result from alterations in the organization of the actin cytoskeleton, cadherinbased cell-cell adhesion and integrin-dependent cell-matrix (substratum) interactions. Because Wrch-1 is a Cdc42-like small GTPase that could modulate all these processes and is differentially expressed in Wnt-1-transformed C57MG cells, Wrch-1 could mediate the effect of Wnt-1 in the morphology of these cells. To test this hy- pothesis, the effect of Wrch-1 on the morphology of C57MG cells was determined. C57MG cells were infected with either the retroviruses expressing Wrch1Q107L or T63N, or the empty vector retrovirus. Overexpression of Q107L, the constitutively active mutant of Wrch-1, causes the cells to become elongated and more refractile, and to have a higher saturation density (Fig. 8). These morphological alterations resemble the morphological transformation phenotype induced by Wnt-1 retroviral infection (Ziemer et al. 2001). In contrast, overexpression of $\mathrm{T} 63 \mathrm{~N}$, the dominant negative mutant of Wrch-1, does not have such a phenotype. These results indicate that Wrch-1 can mimic the effect of Wnt-1 in morphological transformation of C57MG cells.

\section{Discussion}

Three lines of evidence demonstrate that Wrch-1 induction is correlated or associated with the expression of Wnt-1: (1) After retroviral infection of cells, Wrch-1 is selectively expressed in Wnt-1-expressing cells but not in control cells infected with an empty viral vector (Fig. 1A); (2) in the coculture assay, Wrch-1 transcripts are strongly and rapidly induced by Wnt-1 signaling (Fig. 1B); and (3) Wrch-1 is expressed in Wnt-1-induced mouse mammary tumors but not in wild-type mouse mammary glands (Fig. 2). These data do not distinguish between the possibility that the Wrch-1 gene is regulated by Wnt-1 signaling directly or indirectly (i.e., by a transcription factor regulated by Wnt-1). One approach to address this issue would be to determine whether Wrch-1 is up-regulated by Wnt-1 signaling in the absence of new protein synthesis. However, treatment with cycloheximide (an inhibitor of protein synthesis) itself induces Wrch-1 gene expression in C57MG cells (data not shown), eliminating this approach.

The induction of downstream genes by the Wnt-1 signaling pathway could occur by different mechanisms. In the canonical model, Wnt-1 signaling elicits target gene transcription through $\beta$-catenin/TCF-LEF transcription factors by stabilizing $\beta$-catenin /Cadigan and Nusse 1997; Polakis 1999). Most of the identified Wnt-1-responsive genes are induced by this mode (Behrens et al. 1996; He et al. 1998a; van der Heyden et al. 1998; Gradl et al. 1999; Tetsu and McCormick 1999). Alternatively, the accumulated $\beta$-catenin in the cytoplasm could stimulate the activation of other transcription factors, such as CREB, through the cAMP/PKA pathway (Xu et al. 2000), or associate with other transactivation partners, such as Teashirt, to induce gene expression /Gallet et al. 1999). In addition, Wnt-1 could induce gene expression independently of $\beta$-catenin (Ziemer et al. 2001). Recently, the promoter of BTEB2, one of the genes isolated in the same screen as Wrch-1, was shown to be responsive to Wnt-1 signaling in a PKC-sensitive and $\beta$-cateninindependent manner (Ziemer et al. 2001). Indeed, some Wnt family proteins, such as Xenopus Wnt-5A, use the $\mathrm{PKC} /$ calcium pathway rather than $\beta$-catenin/TCF-LEF pathway to activate their target gene expression (Slusarski et al. 1997a,b). Interestingly, Wrch-1 was up-regu- 
Figure 8. Wrch-1 morphologically transforms C57MG cells. C57MG cells were infected with either a retrovirus expressing Wrch-1Q107L or Wrch-1T63N, or an empty retroviral vector. Cells stably expressing each of these proteins were selected for $4 \mathrm{~d}$. The cell morphology was examined by microscopy.
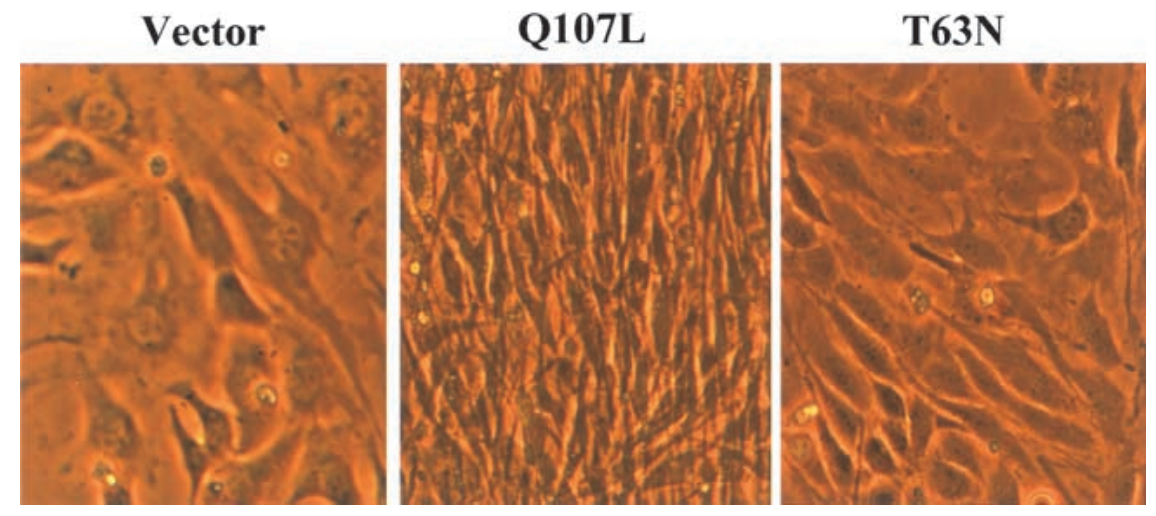

lated in Wnt-1-expressing cells but not in cells expressing the stabilized, transactivation-competent mutants of $\beta$-catenin (Fig. 1A). These results suggest that Wnt-1 might regulate Wrch-1 expression independently of $\beta$-catenin. The isolation and analysis of the Wrch-1 promoter would be required to confirm that Wrch-1 is a direct target of Wnt-1 signaling, and to elucidate the mechanism(s) by which Wrch-1 transcription is regulated.

Identification of Wrch-1 as a Wnt-1-regulated homolog of the Rho family of GTPases is likely to fill a gap between upstream Wnt-1 signaling and its effects on cell morphology, motility, and growth. The Rho-like GTPases act as molecular switches. In response to extracellular signals, they elicit coordinate changes in the organization of the actin cytoskeleton and in gene expression to regulate a variety of physiological processes, including morphogenesis, cell migration, axonal guidance, and cell cycle progression (Van Aelst and D'Souza-Schorey 1997; Hall 1998). Wrch-1 could regulate these processes in response to Wnt-1 signaling. Consistent with this hypothesis, Wrch-1 is predominantly expressed in the embryonic mouse nervous system (Fig. 4B), where Wnt-1 is also predominantly expressed (Shackleford and Varmus 1987). It has been shown that Wnt-1 plays a vital role in the development of the mouse nervous system. Homozygous deletion of the Wnt-1 alleles results in the absence of midbrain and cerebellum, and the Wnt-1-1mice die within $24 \mathrm{~h}$ after birth (McMahon and Bradley 1990). In this scenario, Wrch-1 might act downstream of Wnt-1 signaling to control neural migration and axonal growth.

Wnt-1 is not normally expressed in the mouse mammary gland. However, aberrant activation of Wnt-1 expression in this tissue leads to tumor formation (Nusse et al. 1984). Detection of Wrch-1 expression in Wnt-1 induced mouse mammary tumors, but not in wild-type mouse mammary glands, is consistent with the involvement of Wrch-1 in Wnt-1-induced transformation and tumor formation. The observation that Wrch-1 can mimic the effect of Wnt-1 in morphological transformation of C57MG cells further supports this notion (Fig. 8). Indeed, overexpression or aberrant activation of Rho, Rac, or Cdc42 results in cell transformation, tumor for- mation, and metastasis (Olson et al. 1995; Qiu et al. 1995, 1997; Keely et al. 1997; Clark et al. 2000).

Most of the Rho family GTPases are constitutively expressed in many tissues (Ridley 1999). Their biological activities are induced by extracellular cues that activate their corresponding nucleotide exchange factors (Van Aelst and D'Souza-Schorey 1997). However, expression of several Rho family members, such as RhoB and RhoG, is growth factor inducible, indicating an additional mechanism that regulates their activities, that is, controlling their transcription (Jahner and Hunter 1991; Vincent et al. 1992). Wrch-1 appears to be regulated by both mechanisms. Conceivably, Wnt-1 could elicit Wrch-1 activities by inducing its expression and activating its nucleotide exchange factor(s) simultaneously. Alternatively, the expressed Wrch-1 could be activated by other signaling molecules. Of note is the SH3 binding domain of Wrch-1. This domain could either mediate the association of Wrch-1 with an activator or effector protein, or target Wrch-1 to a specific subcellular compartment. Interestingly, another novel protein has been identified in a yeast two-hybrid screen that can specifically bind to Wrch-1 (E.J. Hsieh, W. Tao, and A. J. Levine, unpubl.). This protein contains three putative SH3 domains and might act as an adaptor for Wrch-1 to target it to an activator or effector. Elucidation of the pathways upstream and downstream of Wrch-1 should lead to a better understanding of the fundamental processes controlled by Wnt-1 signaling.

\section{Materials and methods}

\section{Suppressive subtraction hybridization}

Suppressive subtraction hybridization was performed using the PCR-select cDNA Subtraction kit (Clontech) as previously described (Pennica et al. 1998; Ziemer et al. 2001). The mRNA from C57MG/Wnt-1 cells that had stably expressed Wnt-1 for 3 wk was used to synthesize the Tester cDNA, while the Driver cDNA was made from the parental C57MG cell mRNA.

\section{cDNA library screening}

Clones encoding full-length mouse Wrch-1 were obtained by screening a $\lambda$ gt 10 mouse embryo cDNA library (Clontech) with 
a 297-bp probe from the original partial clone 65.11 (codons for amino acids 207-306 of Wrch-1). Clones encoding full-length human Wrch-1 were isolated by screening $\lambda$ gt10 lung and fetal cDNA libraries with the same probe at low stringency.

\section{Plasmids}

The wild-type Wrch-1 cDNA was subcloned into pcDNA3 (Invitrogen) between HindIII and BamH1 restriction sites by polymerase chain reaction (PCR) to generate pcDNA3-Wrch-1. The constructs encoding Wrch-1Q107L and Wrch-1T63N were generated by introducing mutations in pcDNA3-Wrch-1 using the QuikChange kit for site-directed mutagenesis (Stratagene). The human PAK-1 cDNA was cloned by reverse transcription polymerase chain reaction (RT-PCR) using total RNA from HeLa cells and primers based upon published sequences. The construct encoding the HA-tagged PAK-1 (HA-PAK-1) was generated by subcloning PAK-1 cDNA into the plasmid, pCGN, between $\mathrm{XbaI}$ and $\mathrm{BamH1}$ restriction sites. The plasmid for HAJNK-1 was a gift from Dr. Ze'en Ronai. The sequences of all constructs were verified.

\section{Tissue culture, cell lines, retroviral infection, and transfection}

C57MG, COS-7, Swiss3T3, and 293 cells were maintained in Dulbecco's Modified Eagle Medium (DMEM) supplemented with $10 \%$ fetal bovine serum (FBS). The C57MG cell lines expressing one of the stabilized mutants of $\beta$-catenin, 4145 , and 4145 TV were generated by transfection as described (Xu et al. 2000).

To generate Wrch-1Q107L and $\mathrm{T} 63 \mathrm{~N}$ retroviruses, the $\mathrm{cD}$ NAs encoding Q107L and T63N were subcloned into the retroviral vector pBabePuro at the EcoRI site. The retroviruses expressing Wrch-1Q107L and T63N were generated by transfection of the packaging cell line BOSC23 with pBabePuro containing their cDNA inserts as described (Ziemer et al. 2001).

C57MG cells were infected with an empty vector (pBabePuro) retrovirus or a Wnt-1 retrovirus as described (Xu et al. 2000; Ziemer et al. 2001). Forty-eight hours after infection, cells were split into the medium containing puromycin $(2.5 \mu \mathrm{g} / \mathrm{mL})$ and selected for $4 \mathrm{~d}$ before the RNA was extracted.

Similarly, C57MG cells were infected with an empty vector retrovirus or a retrovirus expressing Wrch-1Q107L or Wrch$1 \mathrm{~T} 63 \mathrm{~N}$, and selected in puromycin for $4 \mathrm{~d}$ before the cell morphology was examined by Normarski microscopy.

All transfections were performed using the lipofectamine reagent (GIBCO BRL) according to manufacturer's protocol.

\section{Northern blot analysis}

Total RNA was isolated from culture cells using the RNeasy Mini kit (QIAGEN) or from tissues using Trizol reagent (GIBCO $\mathrm{BRL}$ ) as directed by the manufacturer. A human multiple tissue Northern blot was purchased from Clontech. Northern blotting was performed as previously described on $10 \mu \mathrm{g}$ total RNA from each sample (Xu et al. 2000; Ziemer et al. 2001). The signals were visualized by autoradiography and quantitated using a PhosphorImager.

\section{Coculture assay}

The cell lines QT6 and QT6/Wnt-1 (a gift from Dr. Harold Varmus, Sloan Kettering Cancer Center, New York) were derived from a quail fibrosarcoma. Wnt-1 expression in the QT6/Wnt-1 cell line was driven by the MMTV promoter. In this assay, QT6 and QT6/Wnt-1 cells were plated on 10-cm tissue culture dishes at such a density that after culturing for $48 \mathrm{~h}$ they would be about $30 \%-40 \%$ confluent. The identical number of C57MG cells was added to dishes containing either QT6 or QT6/Wnt-1 cells. Cells were harvested after different time periods of coculture. Total RNA was extracted and subjected to Northern blot analysis.

\section{In situ hybridization}

In situ hybridization was done as previously described using the ${ }^{32} \mathrm{P}$-labeled sense and anti-sense riboprobes were transcribed from a 279-bp PCR product corresponding to the codons for amino acids 207-306 of mouse Wrch-1.

\section{In vitro PAK-1 assay}

Forty-eight hours after transfection, COS-7 cells were lysed by supervortex in lysis buffer containing $40 \mathrm{mM}$ Hepes (pH 7.4), $1 \%$ Nonidet P40, 2 mM EDTA, $150 \mathrm{mM} \mathrm{NaCl}, 20 \mathrm{mM} \mathrm{NaF}, 10$ $\mathrm{mM} \beta$-glycerophosphate, $1 \mathrm{mM} \mathrm{Na} \mathrm{VO}_{4}, 1 \mathrm{mM} \mathrm{DTT}$, and a combination of protease inhibitors (Complete from Boehringer). HA-PAK-1 was immunoprecipited from the cleared lysates with equal amounts of total proteins $(500 \mu \mathrm{g})$ by incubation with an anti-HA monoclonal antibody $16 \mathrm{~B} 12$ (BAbCO) for $1 \mathrm{~h}$ at $4^{\circ} \mathrm{C}$. Protein-G conjugated agarose beads were used to precipitate the immune complexes. The immunoprecipitates were washed twice with the lysis buffer and once with the kinase reaction buffer that contained $20 \mathrm{mM}$ Hepes (pH 7.4), 20 $\mathrm{mM} \mathrm{MgCl}_{2}, 20 \mathrm{mM} \mathrm{NaF}, 1 \mathrm{mM} \mathrm{Na}_{3} \mathrm{VO}_{4}, 10 \mathrm{mM} \beta$-glycerophosphate, and $1 \mathrm{mM}$ DTT. The PAK-1 activity in the immunoprecipitates was determined in $30 \mu \mathrm{L}$ kinase reaction buffer with an addition of $20 \mu \mathrm{M}$ cold ATP and $10 \mu \mathrm{Ci}\left[\gamma^{-}{ }^{32} \mathrm{P}\right] \mathrm{ATP}$ using HAPAK-1 in the immunoprecipitates as a substrate. After $20 \mathrm{~min}$ at $30^{\circ} \mathrm{C}$, reactions were terminated by addition of the protein loading buffer ( $1 \%$ SDS, $10 \mathrm{mM} \beta$-mercaptoethanol, $0.02 \%$ bromophenol blue). Samples were subject to electrophoresis on a SDS$10 \%$ polyacrylamide gel and detected by autoradiography. Cell lysates containing $60 \mu \mathrm{g}$ of total protein were subjected to Western blot analysis using a PAK-1-specific antiserum (PharMingen).

\section{In vitro JNK-1 assay}

Transfected COS-7 cells were cultured in medium containing $10 \%$ FBS for $24 \mathrm{~h}$ and then serum-starved for $12 \mathrm{~h}$. The HAtagged JNK-1 was immunoprecipitated and the activity of JNK-1 in the immunoprecipitates was determined as described above using the GST-c-Jun protein $(1 \mu \mathrm{g})$ (a gift from Dr. Yigong Shi, Princeton University, NJ) as a substrate. Parallel samples containing $60 \mu \mathrm{g}$ of total protein were processed for Western blot analysis using a JNK-1-specific antiserum (Santa Cruz).

\section{Western blot analysis}

Proteins in the cell lysates from each sample were separated by $10 \%$ SDS-polyacrylamide gel electrophoresis (SDS-PAGE) (60 $\mu \mathrm{g}$ per lane) and then transferred to nitrocellulose membrane. PAK-1 and JNK-1 were detected using specific antibodies (Santa Cruz). Immunoblotting was performed as described previously (Tao et al. 1997).

\section{Recombinant adenoviruses}

Recombinant adenoviruses were generated using the AdEasy system (a gift from Dr. Bert Vogelstein, Johns Hopkins Medical School, Baltimore, $\mathrm{MD}$ ) as described previously (He et al. 
1998b). The cDNAs for Wrch-1Q107L and Wrch-1T63N from the pcDNA3-Wrch-1Q107L and pcDNA3-Wrch-T63N (described above) were subcloned into the plasmid pADTrackCMV between the HindIII and XbaI sites. An E2F-1 cDNA from pCMVE2F-1 was subcloned as a $B a m H 1$ fragment into the BglII site of pADTrack-CMV, and the LacZ gene from pSVB (Clontech) was subcloned as a NotI fragment into the NotI site of pADTrack-CMV. In the pADTrack-CMV, the expression of both GFP and the gene of interest is driven by its own CMV promoter. Thus, the recombinant adenoviruses express GFP and the protein of interest. Recombination in Escherichia coli BJ5183 and transfection of the recombinant plasmids into 293 cells were performed as described. CsCl-banded recombinant adenovirus stocks were prepared as described, diluted with an equal volume of $2 \mathrm{X}$ storage buffer $(50 \%$ glycerol, $4 \mathrm{mM} \mathrm{MgCl}$, $20 \mathrm{mM}$ Tris at $\mathrm{pH} 8.0$ ), and stored at $-20^{\circ} \mathrm{C}$. Viral titers were determined by optical absorbance.

\section{Immunofluorescent analysis}

Swiss 3 T 3 cells $\left(3 \times 10^{5}\right)$ growing on a $1.8 \times 1.8$-cm glass coverslip in a $35-\mathrm{mm}$ dish were infected with the recombinant adenoviruses [Multiple of Infection (MOI): 4000 particle/cell]. Twelve hours postinfection, these cells were serum-starved for $24 \mathrm{~h}$. The cells were fixed with $4 \%$ paraformaldehyde in phosphate-buffered saline (PBS) followed by permeabilization with $0.2 \%$ Triton X-100 in PBS. After treatment with the blocking solution (PBS containing 0.5\% BSA, 10\% horse serum and $0.05 \%$ Tween-20) for $20 \mathrm{~min}$, the cells were incubated with Alexa568 conjugated philloidin $(3$ units $/ \mathrm{mL}$ in the blocking solution) for $30 \mathrm{~min}$ at room temperature. Finally, the cells were mounted with Aqua Poly/Mount (Polysciences) and visualized by confocal microscopy.

\section{Flow cytometry}

Quiescent Swiss 3T3 cells (serum-starved for $48 \mathrm{~h}$ ) were infected with adenoviruses (MOI: 20,000) and then incubated in medium containing $0.1 \%$ FBS for $48 \mathrm{~h}$. Both attached and floating cells were collected, fixed with ethanol, stained with propidium iodide (PI), and analyzed by fluorescence-activated cell sorting (FACS) as previously described (Kalejta et al. 1999).

\section{Acknowledgments}

We thank Dr. Harold Varmus for QT6 and QT6/Wnt-1 cell lines, Dr. Bert Vogelstein for the AdEasy system, Dr. Yigong Shi for the GST-c-Jun protein, Dr. Ze'ev Ronai for the HA-tagged JNK-1 expression plasmid, and Dr. Lisa Ziemer for helpful discussion. We are grateful to J. Goodhouse for expert assistance with confocal microscopy, Andrew Beavis for expert assistance with flow cytometry analysis, and G. Frantz for help with the in situ hybridization. RFK is a Leukemia and Lymphoma Society Fellow. This work was supported by a grant from the National Cancer Institute to AJL.

The publication costs of this article were defrayed in part by payment of page charges. This article must therefore be hereby marked "advertisement" in accordance with 18 USC section 1734 solely to indicate this fact.

\section{References}

Behrens, J., von Kries, J.P., Kuhl, M., Bruhn, L., Wedlich, D, Grosschedl, R., and Birchmeier, W. 1996. Functional interaction of $\beta$-catenin with the transcription factor LEF-1. $\mathrm{Na}$ ture 382: 638-642.

Cadigan, K.M. and Nusse, R. 1997. Wnt signaling: A common theme in animal development. Genes \& Dev. 11:3286-
3305.

Chan, E.F., Gat, U., McNiff, J.M., and Fuchs, E. 1999. A common human skin tumour is caused by activating mutations in $\beta$-catenin. Nat. Genet. 21: 410-413.

Clark, E.A., Golub, T.R., Lander, E.S., and Hynes, R.O. 2000. Genomic analysis of metastasis reveals an essential role for RhoC. Nature 406: 532-535.

Coso, O.A., Chiariello, M., Yu, J.C., Teramoto, H., Crespo, P., $\mathrm{Xu}$, N., Miki, T., and Gutkind, J.S. 1995. The small GTPbinding proteins Rac1 and Cdc42 regulate the activity of the JNK/SAPK signaling pathway. Cell 81: 1137-1146.

Dale, T.C. 1998. Signal transduction by the Wnt family of ligands. Biochem. J. 329: 209-223.

de La Coste, A., Romagnolo, B., Billuart, P., Renard, C.A., Buendia, M.A., Soubrane, O., Fabre, M., Chelly, J., Beldjord, C., Kahn, A., et al. 1998. Somatic mutations of the $\beta$-catenin gene are frequent in mouse and human hepatocellular carcinomas. Proc. Natl. Acad. Sci. 95: 8847-8851.

Dierick, H. and Bejsovec, A. 1999. Cellular mechanisms of wingless/Wnt signal transduction. Curr. Top Dev. Biol. 43: $153-190$.

Gallet, A., Angelats, C., Erkner, A., Charroux, B., Fasano, L., and Kerridge, S. 1999. The C-terminal domain of armadillo binds to hypophosphorylated teashirt to modulate wingless signalling in Drosophila. EMBO J. 18: 2208-2217.

Gradl, D., Kuhl, M., and Wedlich, D. 1999. The Wnt/Wg signal transducer $\beta$-catenin controls fibronectin expression. Mol. Cell. Biol. 19: 5576-5587.

Hall, A. 1998. Rho GTPases and the actin cytoskeleton. Science 279: 509-514.

He, T.C., Sparks, A.B., Rago, C., Hermeking, H., Zawel, L., da Costa, L.T., Morin, P.J., Vogelstein, B., and Kinzler. K.W. 1998a. Identification of c-MYC as a target of the APC pathway. Science 281: 1509-1512.

He, T.C., Zhou, S., da Costa, L.T., Yu, J., Kinzler, K.W., and Vogelstein, B. 1998b. A simplified system for generating recombinant adenoviruses. Proc. Natl. Acad. Sci. 95: 25092514.

Jahner, D. and Hunter, T. 1991. The ras-related gene rhoB is an immediate-early gene inducible by v- Fps, epidermal growth factor, and platelet-derived growth factor in rat fibroblasts. Mol. Cell. Biol. 11: 3682-3690.

Jue, S.F., Bradley, R.S., Rudnicki, J.A., Varmus, H.E., and Brown, A.M.C. 1992. The mouse Wnt-1 gene can act via a paracrine mechanism in transformation of mammary epithelial cells. Mol. Cell. Biol. 12: 321-328.

Kalejta, R.F., Brideau, A.D., Banfield, B.W., and Beavis, A.J. 1999. An integral membrane green fluorescent protein marker, Us9-GFP, is quantitatively retained in cells during propidium iodide-based cell cycle analysis by flow cytometry. Exp. Cell. Res. 248: 322-328.

Keely, P.J., Westwick, J.K., Whitehead, I.P., Der, C.J., and Parise, L.V. 1997. Cdc42 and Rac1 induce integrin-mediated cell motility and invasiveness through PI(3)K. Nature 390: 632636.

Kozma, R., Ahmed, S., Best, A., and Lim, L. 1995. The Rasrelated protein $\mathrm{Cdc} 42 \mathrm{Hs}$ and bradykinin promote formation of peripheral actin microspikes and filopodia in Swiss 3T3 fibroblasts. Mol. Cell. Biol. 15: 1942-1952.

Kuhl, M., Sheldahl, L.C., Park, M., Miller, J.R., and Moon, R.T. 2000. The Wnt/Ca2+ pathway: A new vertebrate Wnt signaling pathway takes shape. Trends Genet. 16: 279-283.

Latres, E., Chiaur, D.S., and Pagano, M. 1999. The human F box protein $\beta$-Trcp associates with the Cull/Skp1 complex and regulates the stability of $\beta$-catenin. Oncogene 18: 849-854.

Lejeune, S., Huguet, E.L., Hamby, A., Poulsom, R., and Harris, 
A.L. 1995. Wnt5a cloning, expression, and up-regulation in human primary breast cancers. Clin. Cancer Res. 1:215222.

Mann, B., Gelos, M., Siedow, A., Hanski, M.L., Gratchev, A., Ilyas, M., Bodmer, W.F., Moyer, M.P., Riecken, E.O., Buhr, H.J., et al. 1999. Target genes of $\beta$-catenin- $T$ cell-factor $/ \mathrm{lym}$ phoid-enhancer-factor signaling in human colorectal carcinomas. Proc. Nat1. Acad. Sci. 96: 1603-1608.

Manser, E., Leung, C., Salihuddin, H., Zhao, Z.S., and Lim, L. 1994. A brain serine/threonine protein kinase activated by Cdc42 and Rac1. Nature 367: 40-46.

Martin, G.A., Bollag, G., McCormick, F., and Abo, A. 1995. A novel serine kinase activated by rac1/CDC42Hs-dependent autophosphorylation is related to PAK65 and STE20. EMBO J. 14: 4385-4390.

Mason, J.O., Kitajewski, J., and Varmus, H.E. 1992. Mutational analysis of mouse Wnt-1 identifies two temperature-sensitive alleles and attributes of Wnt-1 protein essential for transformation of a mammary cell line. Mol. Biol. Cell. 3: $521-533$.

McMahon, A.P. and Bradley, A. 1990. The Wnt-1 (int-1) protooncogene is required for development of a large region of the mouse brain. Cell 62: 1073-1085.

Michiels, F., Habetrs, G.G.M., Stam, J.C., van der Kammen, R.A., and Collard, J.G. 1995. A role for Rac in Tiam-induced membrane ruffling and invasion. Nature 375: 338-340.

Miller, J.R., Hocking, A.M., Brown, J.D., and Moon, R.T. 1999. Mechanism and function of signal transduction by the Wnt/ $\beta$-catenin and $\mathrm{Wnt} / \mathrm{Ca}^{2+}$ pathways. Oncogene 18: 78607872.

Minden, A., Lin, A., Claret, F.X., Abo, A., and Karin, M. 1995. Selective activation of the JNK signaling cascade and c-Jun transcriptional activity by the small GTPases Rac and Cdc42Hs. Cell 81: 1147-1157.

Morin, P.J., Sparks, A.B., Korinek, V., Barker, N., Clevers, H., Vogelstein, B., and Kinzler, K.W. 1997. Activation of $\beta$-catenin-Tcf signaling in colon cancer by mutations in $\beta$-catenin or APC. Science 275: 1787-1790.

Nobes, C.D. and Hall, A. 1995. Rho, rac, and cdc42 GTPases regulate the assembly of multimolecular focal complexes associated with actin stress fibers, lamellipodia, and filopodia. Cell 81: 53-62.

Nusse, R., van Ooyen, A., Cox, D., Fung, Y.K., and Varmus, H. 1984. Mode of proviral activation of a putative mammary oncogene (int-1) on mouse chromosome 15. Nature 307: 131-136.

Olson, M.F., Ashworth, A., and Hall, A. 1995. An essential role for Rho, Rac, and Cdc42 GTPases in cell progression through G1. Science 269: 1270-1272.

Parkin, N.T., Kitajewski, J., and Varmus, H.E. 1993. Activity of Wnt-1 as a transmembrane protein. Genes \& Dev. 7:21812193.

Peifer, M. and Polakis, P. 2000. Wnt signaling in oncogenesis and embryogenesis-A look outside the nucleus. Science 287: 1606-1609.

Pennica, D., Swanson, T.A., Welsh, J.W., Roy, M.A., Lawrence, D.A., Lee, J., Brush, J., Taneyhill, L.A., Deuel, B., Lew, M., et al. 1998. WISP genes are members of the connective tissue growth factor family that are up-regulated in wnt-1-transformed cells and aberrantly expressed in human colon tumors. Proc. Nat1. Acad. Sci. 95: 14717-14722.

Polakis, P. 1999. The oncogenic activation of $\beta$-catenin. Curr. Opin. Genet. Dev. 9: 15-21.

Polakis, P. 2000. Wnt Signaling and Cancer. Genes \& Dev. 14: $1837-1851$.

Qiu, R.G., Chen, J., Kirn, D., McCormick, F., and Symons, M.
1995. An essential role for Rac in Ras transformation. $\mathrm{Na}$ ture 374: 457-459.

Qiu, R.G., Abo, A., McCormick, F., and Symons, M. 1997. Cdc42 regulates anchorage-independent growth and is necessary for Ras transformation. Mol. Cell. Biol. 17: 34493458.

Ridley, A. 1999. Rho family proteins and regulation of the actin cytoskeleton. In Cytoskeleton and small G proteins (ed. P. Jeanteur), pp. 1-16. Springer, Heidelberg, Germany.

Rubinfeld, B., Robbins, P., El-Gamil, M., Albert, I., Porfiri, E., and Polakis, P. 1997. Stabilization of $\beta$-catenin by genetic defects in melanoma cell lines. Science 275: 1790-1792.

Shackleford, G.M. and Varmus, H.E. 1987. Expression of the proto-oncogene int- 1 is restricted to postmeiotic male germ cells and the neural tube of mid-gestational embryos. Cell 50: 89-95.

Shan, B. and Lee, W.H. 1994. Deregulated expression of E2F-1 induces S-phase entry and leads to apoptosis. Mol. Cell. Biol. 14: 8166-8173.

Slusarski, D.C., Corces, V.G., and Moon, R.T. 1997a. Interaction of Wnt and a Frizzled homologue triggers G-proteinlinked phosphatidylinositol signalling. Nature 390:410413.

Slusarski, D.C., Yang-Snyder, J., Busa, W.B., and Moon, R.T. 1997b. Modulation of embryonic intracellular Ca2+ signaling by Wnt-5A. Dev. Biol. 182: 114-120.

Strutt, D.I., Weber, U., and Mlodzik, M. 1997. The role of RhoA in tissue polarity and Frizzled signaling. Nature 387: 292295.

Tao, W., Kurschner, C., and Morgan, J.I. 1997. Modulation of cell death in yeast by the Bcl-2 family of proteins. J. Biol. Chem. 272: 15547-15552.

Tetsu, O. and McCormick, F. 1999. Beta-catenin regulates expression of cyclin D1 in colon carcinoma cells. Nature 398: 422-426.

Tsukamoto, A.S. 1988. Expression of the int-1 gene in transgenic mice is associated with mammary gland hyperplasia and adenocarcinomas in male and female mice. Cell 55: 619625 .

Van Aelst, L.V. and D'Souza-Schorey, C. 1997. Rho GTPases and signal networks. Genes \& Dev. 11: 2295-2322.

van der Heyden, M.A., Rook, M.B., Hermans, M.M., Rijksen, G., Boonstra, J., Defize, L.H., and Destree, O.H. 1998. Identification of connexin43 as a functional target for Wnt signalling. J. Cell. Sci. 111: 1741-1749.

Vider, B.-Z., Zimber, A., Chastre, E., Prevot, S., Gespach, C., Estlein, D., Wolloch, Y., Tronick, S.R., Gazit, A., and Yaniv, A. 1996. Evidence for the involvement of the Wnt 2 gene in human colorectal cancer. Oncogene 12: 153-158.

Vincent, S., Jeanteur, P., and Fort, P. 1992. Growth-regulated expression rho $G$, a new member of the ras homolog gene family. Mol. Cell. Biol. 12: 3138-3143.

Vojtek, A.B. and Cooper, J.A. 1995. Rho family members: Activators of MAP kinase cascades. Cell 82: 527-529.

$\mathrm{Xu}$, L., Corcoran, R.B., Welsch, J.W., Pennica, D., and Levine A.J. 2000. WISP-1 is a Wnt-1- and $\beta$-catenin-responsive oncogene. Genes \& Dev. 14: 585-595.

Zeng, L., Fagotto, F., Zhang, T., Hsu, W., Vasicek, T.J., Perry III, W.L., Lee, J.J., Tilghman, S.M., Gumbiner, B.M., and Costantini, F. 1997. The mouse Fused locus encodes Axin, an inhibitor of the Wnt signaling pathway that regulates embryonic axis formation. Cell 90: 181-192.

Ziemer, L.T., Pennica, D., and Levine, A.J. 2001. Identification of a mouse homolog of human BTEB2 transcription factor as a $\beta$-catenin-independent Wnt-1-responsive gene. Mol. Cell. Biol. 21: 562-574. 


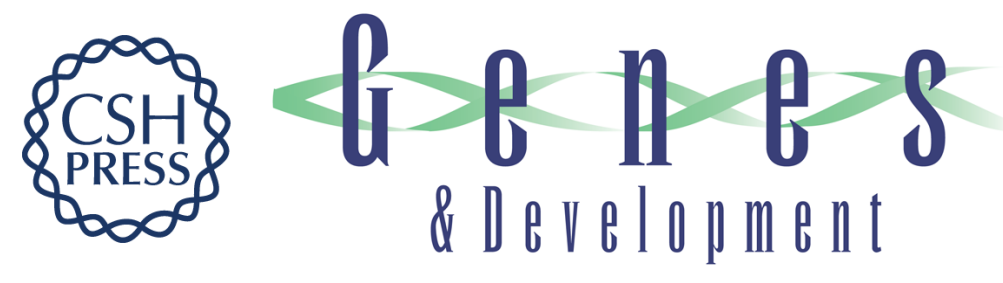

\section{Wrch-1, a novel member of the Rho gene family that is regulated by Wnt-1}

Weikang Tao, Diane Pennica, Lifeng Xu, et al.

Genes Dev. 2001, 15:

Access the most recent version at doi:10.1101/gad.894301

References This article cites 56 articles, 28 of which can be accessed free at: http://genesdev.cshlp.org/content/15/14/1796.full.html\#ref-list-1

License

Email Alerting

Receive free email alerts when new articles cite this article - sign up in the box at the top Service right corner of the article or click here.

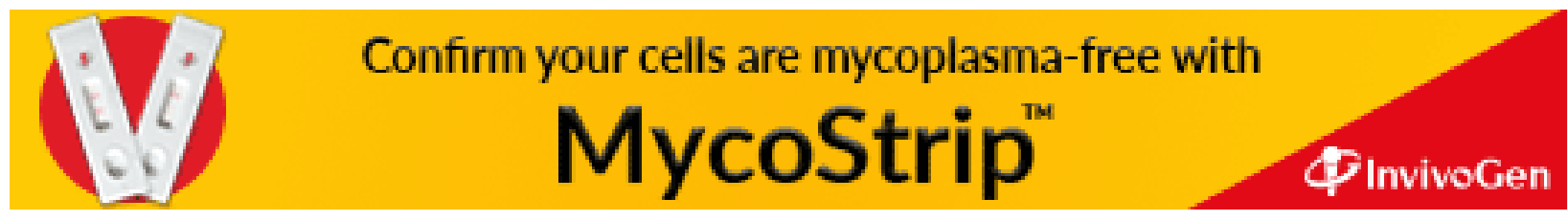

